\title{
Linkages among Soil Fertilization Regimes, Chemical Properties and Maize Grains Yield in Humid Tropic
}

\author{
Relações entre Regimes de Fertilização do Solo, Propriedades Químicas e Produtividade de Grãos \\ de Milho no Trópico Úmido
}

Relaciones entre los Regímenes de Fertilización del Suelo, las Propiedades Químicas y el Rendimiento de Granos de Maíz en el Trópico Húmedo

\begin{abstract}
We hypothesize that there is a linkage among different soil fertilization regimes, soil chemical attributes and maize grains yield. We aimed to evaluate the relationships between different soil fertilization regimes, soil chemical properties and maize grains yield. The experiment was performed in northeastern Brazil, in a randomized block design, at an area divided into 24 plots with six treatments and four replicates (Nitrogen (N); Leucaena (L); Nitrogen+Leucaena $(\mathrm{N}+\mathrm{L})$; Humic Acid+Leucaena (HA+L); Humic Acid+Nitrogen (HA+N) and Humic Acid+Nitrogen+Leucaena $(\mathrm{HA}+\mathrm{N}+\mathrm{L}))$. Each plot was cropped with maize (Zea mays L.) and the grains yield was estimated. Soil samples were collected at depths of $0-5 \mathrm{~cm}, 5-10 \mathrm{~cm}$ and $10-20 \mathrm{~cm}$. Potential acidity, pH, soil organic carbon (SOC), available phosphorus, exchangeable potassium, calcium and magnesium, cation exchange capacity (CEC), sum of basic cations (SBC) and base saturation (BS) were determined. Principal component analysis (PCA) was used to correlate soil chemical attributes with maize yield. Calcium, magnesium, available $\mathrm{P}$ and SBC were related to the maize grains yield in upper soil layer, especially at nitrogen fertilization. This research confirms the hypothesis that there is a linkage between different soil fertilization regimes, soil properties and the maize grains yield.
\end{abstract}

Keywords: Fertilizers; Macronutrients; Green manure.

\section{Resumo}

Nossa hipótese é de que existe uma relação entre diferentes regimes de fertilização do solo, atributos químicos do solo e rendimento de grãos de milho. Nosso objetivo foi avaliar as relações entre diferentes regimes de fertilização do solo, propriedades químicas do solo e rendimento de grãos de milho. O experimento foi realizado no Nordeste do Brasil, utilizando o delineamento em blocos casualizados, em uma área dividida em 24 parcelas com seis tratamentos e quatro repetições (Nitrogênio $(\mathrm{N})$; Leucena $(\mathrm{L})$; Nitrogênio+Leucena $(\mathrm{N}+\mathrm{L})$; Ácido Húmico+Leucena $(\mathrm{HA}+\mathrm{L})$; Ácido Húmico+Nitrogênio $(\mathrm{HA}+\mathrm{N})$ e Ácido Húmico+Nitrogênio+Leucena $(\mathrm{HA}+\mathrm{N}+\mathrm{L}))$. Cada parcela foi cultivada com milho (Zea mays L.) e estimou-se a produtividade de grãos. Amostras de solo foram coletadas em profundidades de 0-5 cm, 5-10 cm e 10-20 cm. Foram determinados a acidez potencial, pH, carbono orgânico do solo (SOC), fósforo disponível, potássio trocável, cálcio e magnésio, capacidade de troca catiônica (CEC), soma de cátions básicos (SBC) e saturação por bases (BS). A análise de componentes principais (PCA) foi utilizada para correlacionar os atributos 
químicos do solo com a produtividade do milho. Cálcio, magnésio, P disponível e SBC estavam associados ao rendimento de grãos de milho na camada superior do solo, especialmente na fertilização com nitrogênio. Esta pesquisa confirma a hipótese de que existe uma relação entre os diferentes regimes de fertilização do solo, propriedades do solo e rendimento de grãos de milho.

Palavras-chave: Fertilizantes; Macronutrientes; Manejo verde.

\section{Resumen}

Nuestra hipótesis es que existe una relación entre diferentes regímenes de fertilización del suelo, atributos químicos del suelo y rendimiento de grano de maíz. Nuestro objetivo fue evaluar las relaciones entre diferentes regímenes de fertilización del suelo, propiedades químicas del suelo y rendimiento de grano de maíz. El experimento se llevó a cabo en el noreste de Brasil, utilizando un diseño de bloques al azar, en un área dividida en 24 parcelas con seis tratamientos y cuatro repeticiones (Nitrógeno (N); Leucaena (L); Nitrógeno+Leucaena (N+L); Ácido Húmico+Leucaena $(\mathrm{HA}+\mathrm{L})$; Ácido Húmico+Nitrógeno $(\mathrm{HA}+\mathrm{N})$ y Ácido Húmico+Nitrógeno+Leucaena $(\mathrm{HA}+\mathrm{N}+\mathrm{L})$ ). Cada parcela se cultivó con maíz (Zea mays L.) y se estimó el rendimiento de grano. Se recolectaron muestras de suelo a profundidades de 0 a $5 \mathrm{~cm}, 5$ a $10 \mathrm{~cm}$ y 10 a $20 \mathrm{~cm}$. Se determinó la acidez potencial, pH, carbono orgánico del suelo (SOC), fósforo disponible, potasio intercambiable, calcio y magnesio, capacidad de intercambio catiónico (CEC), suma de cationes básicos (SBC) y saturación de bases (BS). Se utilizó el análisis de componentes principales (PCA) para correlacionar los atributos químicos del suelo con el rendimiento del maíz. El calcio, el magnesio, el $\mathrm{P}$ disponible y el SBC se asociaron con el rendimiento de grano de maíz en la capa superior del suelo, especialmente en la fertilización con nitrógeno. Esta investigación confirma la hipótesis de que existe una relación entre diferentes regímenes de fertilización del suelo, propiedades del suelo y rendimiento de grano de maíz.

Palabras clave: Fertilizantes; Macronutrientes; Gestión ecológica.

\section{Introduction}

To better understand about soil and plant system it is necessary to know how the interactions between the two work. In these interactions, any change in soil conditions also causes transformations in the plant. These transformations in plant, in turn, also alter the soil, in other words, there is feedback. Early civilizations already knew the importance of these interactions and they recognized that agricultural productivity was affected by different soils (Ehrenfeld et al., 2005). In this context, Moura et al. (2009), argue that associations between plant productivity and soil chemical attributes are still unclear.

The soil is a biosphere component, and it results of the combination between living and non-living organisms. Macro and micronutrients present in the soils play a key role in the plant's life (promoting their growth) and in the evolution of own soil (Morar and Peterlicean, 2014). Calcium, magnesium, nitrogen, phosphorous and potassium are some examples of macronutrients, which are required in large quantities $(>0.1 \%$ of dry mass) and plants need of each of them to develop and complete their life cycle (Maathuis, 2009). Essential cellular components, as nucleic acids and proteins are built by macronutrients (Morgan and Connolly, 2013).

In general, the soil is characterized by low concentrations of inorganic macronutrients, being that this availability can change depending on place (Maathuis, 2009). According to Morgan and Connolly (2013), agriculture may be greatly impacted by nutrients deficiency, decreasing plant quality and crop yield. In this sense, Ehrenfeld et al. (2005) recognize that probably associations between chemical and biogeochemical features of soil and plants are very difficult to evaluate. A study carried out in northeast Vietnã by Anh et al. (2014) suggests that macronutrient contents can be changed by alterations in land and in ground cover. In this context, there are already some studies about which fertilizer (mineral or organic) is most efficient to increase soil macronutrients contents and crop yield, though the conclusion also depends on many other factors.

Here, we hypothesize that there is a linkage among different soil fertilization regimes, soil chemical attributes and maize grains yield. Since the knowledge about fertilization procedures and macronutrients content is important to enhance crop yield, these interactions need further investigation. Then the aim of this study was to evaluate the relationships between different soil fertilization regimes, soil chemical properties and maize grains yield. 


\section{Methodology}

\subsection{Study Site}

The experiment was performed at Brejo city, located in Maranhão state, northeastern Brazil ( $\left.3^{\circ} 38^{\prime} \mathrm{S}, 42^{\circ} 58^{\prime} \mathrm{W}\right)$. The climate is humid tropical with 1200-1400 mm of average annual precipitation and average annual temperature is above $27^{\circ} \mathrm{C}$. The soil is classified as Arenic Hapludult (Soil Survey Staff, 2010), presenting a flat topography (slope < 1\%) with the following characteristics: $\mathrm{pH} 4.4\left(0.01 \mathrm{M} \mathrm{CaCl}_{2}\right)$; organic $\mathrm{C} 15.5 \mathrm{~g} \mathrm{~kg}^{-1}$; potential acidity 4.7 , and CEC $7.9 \mathrm{mmol}(\mathrm{c}) \mathrm{dm}^{-3} ; \mathrm{Ca}$ 2.6, $\mathrm{Mg} 0.5$, and $\mathrm{K} 0.1 \mathrm{mmol}_{\mathrm{c}}$ ) $\mathrm{dm}^{-3} ; \mathrm{P} 3.7 \mathrm{~g} \mathrm{dm}^{-3}$ (resin); base saturation $40.2 \%$; and a sandy textural class.

The experimental area was established in 2012 and consists of an alley cultivation system with Leucaena (Leucaena leucocephala), planted with an inter-row spacing of $4 \mathrm{~m}$ and an inter-plant spacing of $0.5 \mathrm{~m}$.

In January 2015, the area between the rows of the Leucaena was divided into 24 plots of $4 \times 10 \mathrm{~m}$ with six treatments and four replicates $(\mathrm{R})$ in a randomized block design. The treatments were: $133 \mathrm{~kg} \mathrm{ha}^{-1}$ of urea, as a source of Nitrogen $(\mathrm{N}) ; 15$ $\mathrm{t} \mathrm{ha}^{-1}$ of Leucaena leucocephala - Leucaena (L); $133 \mathrm{~kg} \mathrm{ha}^{-1}$ of urea $+15 \mathrm{tha}^{-1}$ of Leucaena (N+L); $5001 \mathrm{ha}^{-1}$ of humic acid+15 $\mathrm{t} \mathrm{ha}^{-1}$ of Leucaena (HA+L); $5001 \mathrm{ha}^{-1}$ of humic acid+133 kg ha ${ }^{-1}$ of urea $(\mathrm{HA}+\mathrm{N})$ and $5001 \mathrm{ha}^{-1}$ of humic acid+133 kg ha-1 of urea $+15 \mathrm{t} \mathrm{ha}^{-1}$ of Leucaena $(\mathrm{HA}+\mathrm{N}+\mathrm{L})$. All treatments received $120 \mathrm{~kg} \mathrm{ha}^{-1}$ of $\mathrm{P}_{2} \mathrm{O}_{5}, 60 \mathrm{~kg} \mathrm{ha}^{-1}$ of $\mathrm{K}_{2} \mathrm{O}$ and $25 \mathrm{~kg} \mathrm{ha}^{-1}$ of $\mathrm{ZnSO}_{4}$. These doses were defined according to the result of the soil analysis.

\subsection{Maize Grains Yield}

Each plot was cropped with maize (Zea mays L.), variety QPM BR 473, in March 2015 in a total area of 1,280 m². At physiological maturity, ten cobs were collected from each plot, and their grains were extracted. The grains yield was estimated in $\mathrm{Mg} \mathrm{ha}^{-1}$ from the total grain mass in each plot and the number of plants per hectare.

\subsection{Soil Chemical Attributes}

Field sample collections and laboratory analyzes were carried out according to Moura et al. (2008).

Soil samples were collected with a duty auger, at depths of $0-5 \mathrm{~cm}, 5-10 \mathrm{~cm}$ and $10-20 \mathrm{~cm}$ from each plot in July 2015. In the laboratory, each sample was analyzed to determine the $\mathrm{pH}\left(0.01 \mathrm{M} \mathrm{CaCl}_{2}\right.$ suspension, $1: 2.5 \mathrm{soil} / \mathrm{solution}$, v/v), the soil organic carbon (SOC) (Walkley-Black), the exchangeable K, Ca, Mg (resin) and potential acidity (H + Al) (SMP method) according Raij et al. (2001). For K determination, UV-Vis spectrophotometry was used. Available P was determined by the Mehlich 1 . We determined the cation exchange capacity $\left(\mathrm{CEC}=\mathrm{K}^{+}+\mathrm{Ca}^{2+}+\mathrm{Mg}^{2+}+\mathrm{H}^{+}+\mathrm{Al}^{3+}\right)$ and the sum of basic cations $\left(\mathrm{SBC}=\mathrm{K}^{+}+\mathrm{Ca}^{2+}+\mathrm{Mg}^{2+}\right)$, and these were used to calculate base saturation $(\mathrm{BS}=[\mathrm{SBC} / \mathrm{CEC}] \cdot 100)$.

\subsection{Statistical analyses}

For statistical analysis, the one-way ANOVA was conducted to determine the significance of the difference in means of soil chemical attributes and maize grains yield. Distributions of all variables were assessed using the Shapiro-wilk test, and they were transformed before analysis where necessary to achieve normal distributions. Duncan test was used to determine which differences are significant. Principal component analysis (PCA) was used, after standardization of data, with the main objective to identify the principal soil chemical attributes associated with maize yield. Statistica version 7 (Statsoft Inc., 2004) was used in all analyses. 


\section{Results}

\subsection{Maize grains yield}

Plots that received nitrogen fertilizer produced significantly higher maize grains yield than that did not receive it $(\mathrm{p}<$ 0.05 ). The maize grains yield at $\mathrm{N}+\mathrm{L}$ was significantly higher than in the other treatments (Table 1 ).

Table 1. Maize grains yield under different soil fertilization regimes.

\begin{tabular}{|c|c|}
\hline Treatment & Grains Yield $\left(\mathrm{kg} \mathrm{ha}^{-1}\right)$ \\
\hline $\mathrm{HA}+\mathrm{N}$ & $4,025 \mathrm{~b}$ \\
\hline $\mathrm{HA}+\mathrm{N}+\mathrm{L}$ & $4,617 b$ \\
\hline $\mathrm{L}$ & $1,472 \mathrm{c}$ \\
\hline $\mathrm{HA}+\mathrm{L}$ & $1,600 \mathrm{c}$ \\
\hline $\mathrm{N}$ & $3,935 b$ \\
\hline $\mathrm{N}+\mathrm{L}$ & $5,385 \mathrm{a}$ \\
\hline \multicolumn{2}{|c|}{ 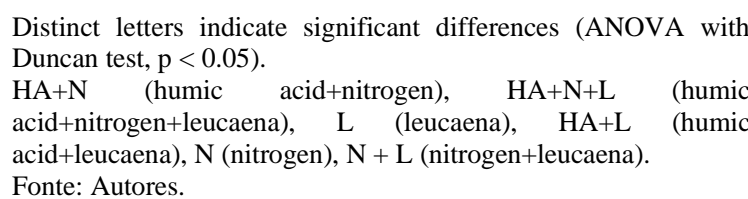 } \\
\hline
\end{tabular}

\subsection{Effect of different soil fertilization regimes on soil chemical properties}

The potential acidity concentrations were the lowest in the upper soil layer $(0-5 \mathrm{~cm})$ and showed a tendency to increase with increasing soil depth, except at $\mathrm{HA}+\mathrm{L}$ and $\mathrm{N}$, where the depth of 5-10 $\mathrm{cm}$ showed the highest concentration and the lowest concentration, respectively. The different treatments did not change the potential acidity levels within the soil profile $(0-20 \mathrm{~cm})(\mathrm{p}>0.05)$ (Figure 1).

Figure 1. Effects of different soil fertilization regimes on potential acidity and $\mathrm{pH}$ at different soil depths. Horizontal bars indicate standard deviation $(\mathrm{p}<0.05)$.
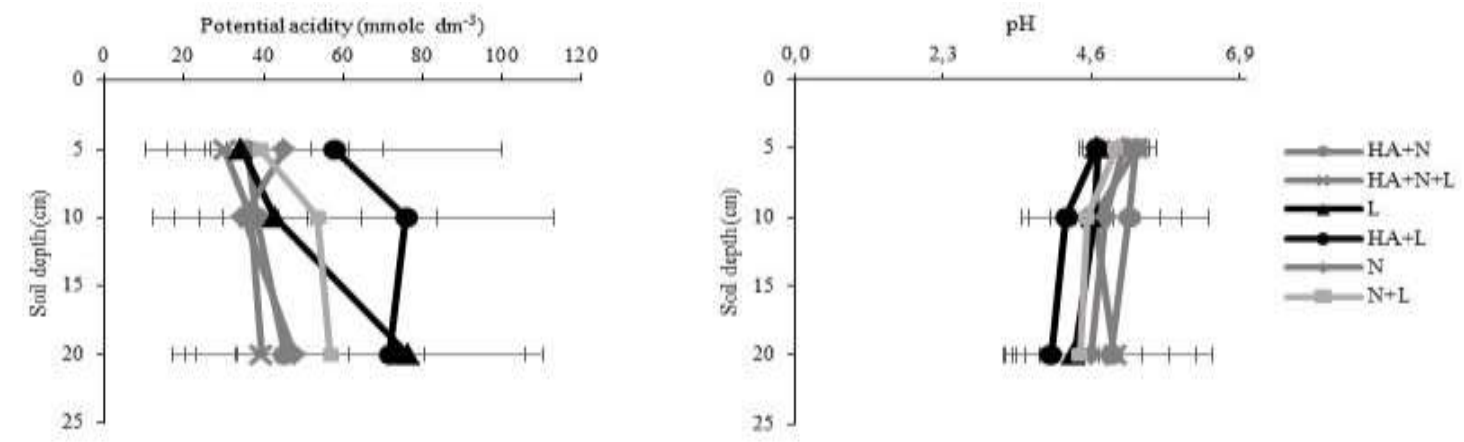

Fonte: Autores.

Within the 0-20 cm soil layer, $\mathrm{pH}$ concentrations were the highest at $0-5 \mathrm{~cm}$ layer and showed a tendency to decrease at 10-20 cm soil depth, except at $\mathrm{HA}+\mathrm{N}+\mathrm{L}$ treatment. The $\mathrm{HA}+\mathrm{N}$ treatment had significantly greater concentration $(\mathrm{p}<0.05)$ in $\mathrm{pH}$ than treatments of $\mathrm{L}$ and $\mathrm{HA}+\mathrm{L}$ at $0-5 \mathrm{~cm}$ depth, with increases of 0.6 in both treatments. There was no significant difference between treatments at the other soil depths $(\mathrm{p}>0.05)$ (Figure 1).

The available $\mathrm{P}$ concentrations showed a tendency to decrease with increasing soil depth, except at N. However, within the $0-20 \mathrm{~cm}$ soil layer no significant differences in available $\mathrm{P}$ concentrations were observed between the treatments $(\mathrm{p}$ $>0.05$ ) (Figure 2). 
Figure 2. Effects of different soil fertilization regimes on available P and SOC at different soil depths. Horizontal bars indicate standard deviation $(\mathrm{p}<0.05)$.
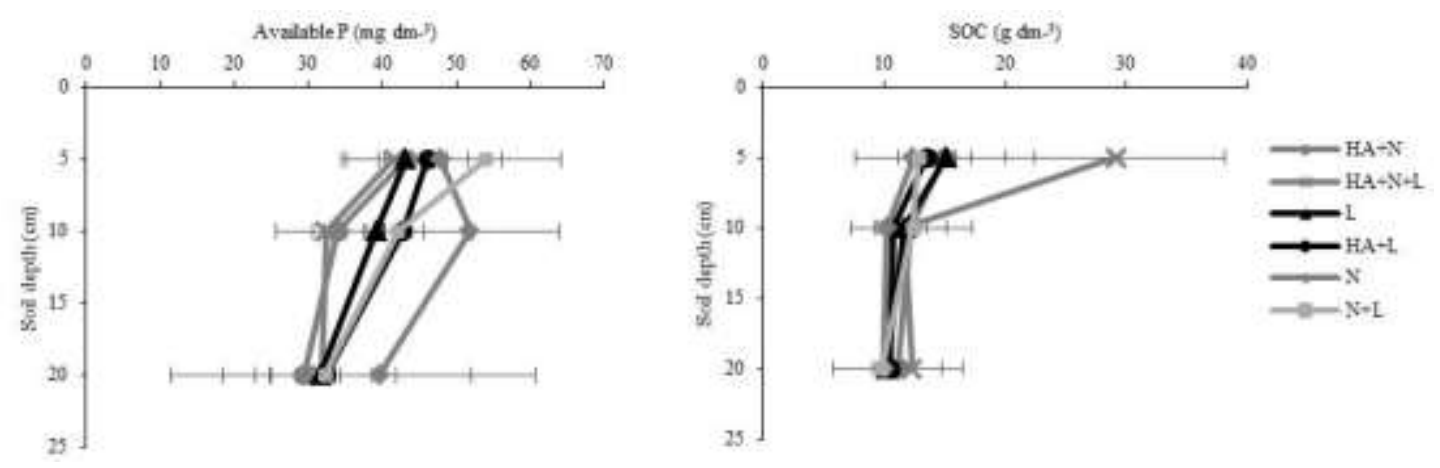

Fonte: Autores.

The SOC concentrations were the largest in the upper soil layer $(0-5 \mathrm{~cm})$ and showed a tendency to decrease with increasing soil depth, except at $\mathrm{HA}+\mathrm{N}+\mathrm{L}$, where the depth of 5-10 $\mathrm{cm}$ showed the lowest content. The treatments did not change the SOC levels within the soil profile $(0-20 \mathrm{~cm})(\mathrm{p}>0.05)$ (Figure 2).

Compared with $\mathrm{N}$ alone, $\mathrm{HA}+\mathrm{L}$ and $\mathrm{N}+\mathrm{L}$ showed a significant increase of $0.3 \mathrm{mmol}_{\mathrm{c}} \mathrm{dm}^{-3}$ in $\mathrm{K}^{+}$at $0-5 \mathrm{~cm}$ soil depth $(\mathrm{p}<0.05)$. Compared with $\mathrm{N}$ alone, $\mathrm{HA}+\mathrm{N}, \mathrm{HA}+\mathrm{N}+\mathrm{L}$ and $\mathrm{N}+\mathrm{L}$ resulted in significant increments of $12.8,13.5$ and $12.8 \mathrm{mmol}_{\mathrm{c}}$ $\mathrm{dm}^{-3}$ in $\mathrm{Ca}^{2+}$ at $0-5 \mathrm{~cm}$ soil depth, respectively $(\mathrm{p}<0.05)$. No significant difference in the $\mathrm{K}^{+}$and $\mathrm{Ca}^{2+}$ concentrations was recorded in the 5-20 cm soil layers and no significant difference in $\mathrm{Mg}^{2+}$ concentration was recorded in the 0-20 $\mathrm{cm}$ soil layer between all the treatments (Table 2).

The use of $\mathrm{HA}+\mathrm{N}+\mathrm{L}$ resulted in significantly highest concentration of $\mathrm{SBC}$, leading to increases of $6.82,9.73$ and $2.53 \mathrm{mmol}_{\mathrm{c}} \mathrm{dm}^{-3}$ compared with $\mathrm{HA}+\mathrm{L}, \mathrm{N}$ and $\mathrm{N}+\mathrm{L}$ at $0-5 \mathrm{~cm}$ soil depth, respectively ( $\mathrm{p}<0.05$ ). The use of HA+L recorded a significantly highest concentration of CEC compared with all other treatments, with decreases of 14.88, 20.93, 14.93, 15.54 and $14.30 \mathrm{mmol}_{\mathrm{c}} \mathrm{dm}^{-3}$ at $\mathrm{HA}+\mathrm{N}, \mathrm{HA}+\mathrm{N}+\mathrm{L}, \mathrm{L}, \mathrm{N}$ and $\mathrm{N}+\mathrm{L}$, respectively $(\mathrm{p}<0.05)$. Compared with $\mathrm{HA}+\mathrm{L}$ and $\mathrm{N}$, the BS concentrations resulted in significant increments of about $14 \%-15 \%$ in both $\mathrm{HA}+\mathrm{N}$ and $\mathrm{HA}+\mathrm{N}+\mathrm{L}$ at $0-5 \mathrm{~cm}$ soil depth $(\mathrm{p}<$ 0.05). No significant difference in SBC, CEC and BS concentrations was recorded at 5-20 cm soil depth (p > 0.05) (Table 2). 
Table 2. Effects of different soil fertilization regimes on exchangeable $\mathrm{K}^{+}, \mathrm{Ca}^{2+}$ and $\mathrm{Mg}^{2+}$ and SBC, CEC and BS.

\begin{tabular}{|c|c|c|c|c|c|c|c|}
\hline \multirow[t]{2}{*}{$\begin{array}{l}\text { Soil } \\
\text { depth }\end{array}$} & \multirow[t]{2}{*}{ Treatment } & \multirow[t]{2}{*}{$\mathrm{K}^{+}$} & \multirow[t]{2}{*}{$\mathrm{Ca}^{2+}$} & \multirow[t]{2}{*}{$\mathrm{Mg}^{2+}$} & SBC & \multirow[t]{2}{*}{ CEC } & \multirow{2}{*}{$\begin{array}{l}\mathrm{BS} \\
\%\end{array}$} \\
\hline & & & & & $\mathrm{mmol}_{\mathrm{c}} / \mathrm{dm}^{3}$ & & \\
\hline \multirow[t]{6}{*}{$0-5$} & $\mathrm{HA}+\mathrm{N}$ & $1.8 \pm 0.2 \mathrm{ab}$ & $35.8 \pm 2.2 \mathrm{a}$ & $10.8 \pm 4.9 \mathrm{a}$ & $48.27 \pm 11.60 \mathrm{ab}$ & $84.13 \pm 13.03 b$ & $61.27 \pm 13.01 \mathrm{a}$ \\
\hline & $\mathrm{HA}+\mathrm{N}+\mathrm{L}$ & $1.8 \pm 0.2 \mathrm{ab}$ & $36.5 \pm 2.7 \mathrm{a}$ & $9.8 \pm 5.1 \mathrm{a}$ & $47.97 \pm 1.09 \mathrm{a}$ & $78.08 \pm 8.86 b$ & $61.46 \pm 3.94 \mathrm{a}$ \\
\hline & $\mathrm{L}$ & $2.1 \pm 0.1 \mathrm{ab}$ & $35.0 \pm 4.5 \mathrm{ab}$ & $12.5 \pm 4.0 \mathrm{a}$ & $49.65 \pm 16.95 \mathrm{ab}$ & $84.08 \pm 10.04 b$ & $58.97 \pm 20.16 a b$ \\
\hline & $\mathrm{HA}+\mathrm{L}$ & $2.2 \pm 0.1 \mathrm{a}$ & $28.8 \pm 3.5 \mathrm{ab}$ & $10.3 \pm 4.6 \mathrm{a}$ & $41.15 \pm 2.03 b$ & $99.01 \pm 10.95 \mathrm{a}$ & $46.40 \pm 6.45 b$ \\
\hline & $\mathrm{N}$ & $1.9 \pm 0.1 b$ & $23.0 \pm 9.9 \mathrm{~b}$ & $13.4 \pm 4.3 \mathrm{a}$ & $38.24 \pm 5.56 b$ & $83.47 \pm 13.5 b$ & $46.95 \pm 5.43 b$ \\
\hline & $\mathrm{N}+\mathrm{L}$ & $2.2 \pm 0.1 \mathrm{a}$ & $35.8 \pm 2.4 \mathrm{a}$ & $7.5 \pm 0.6 \mathrm{a}$ & $45.44 \pm 0.18 b$ & $84.71 \pm 13.97 b$ & $54.14 \pm 18.82 \mathrm{ab}$ \\
\hline \multirow[t]{6}{*}{$5-10$} & $\mathrm{HA}+\mathrm{N}$ & $1.4 \pm 0.2 \mathrm{a}$ & $28.8 \pm 15.6 a$ & $8.8 \pm 1.5 \mathrm{a}$ & $38.89 \pm 14.76 a$ & $77.29 \pm 21.77 \mathrm{a}$ & $52.85 \pm 21.43 \mathrm{a}$ \\
\hline & $\mathrm{HA}+\mathrm{N}+\mathrm{L}$ & $1.4 \pm 0.3 \mathrm{a}$ & $26.5 \pm 3.9 a$ & $7.9 \pm 3.8 \mathrm{a}$ & $35.80 \pm 4.50 \mathrm{a}$ & $72.40 \pm 9.34 \mathrm{a}$ & $49.68 \pm 5.50 \mathrm{a}$ \\
\hline & $\mathrm{L}$ & $1.5 \pm 0.7 \mathrm{a}$ & $26.5 \pm 10.1 \mathrm{a}$ & $7.5 \pm 6.6 \mathrm{a}$ & $35.47 \pm 15.31 \mathrm{a}$ & $78.27 \pm 11.10 \mathrm{a}$ & $44.21 \pm 14.38 \mathrm{a}$ \\
\hline & $\mathrm{HA}+\mathrm{L}$ & $1.6 \pm 0.5 \mathrm{a}$ & $18.3 \pm 4.6 \mathrm{a}$ & $8.0 \pm 1.4 \mathrm{a}$ & $27.86 \pm 6.06 a$ & $103.78 \pm 38.55 a$ & $29.94 \pm 13.53 \mathrm{a}$ \\
\hline & $\mathrm{N}$ & $1.7 \pm 1.0 \mathrm{a}$ & $31.3 \pm 13.7 \mathrm{a}$ & $6.3 \pm 1.5 \mathrm{a}$ & $39.21 \pm 15.30 \mathrm{a}$ & $74.08 \pm 6.92 \mathrm{a}$ & $53.33 \pm 22.06 \mathrm{a}$ \\
\hline & $\mathrm{N}+\mathrm{L}$ & $1.4 \pm 0.2 \mathrm{a}$ & $24.8 \pm 7.5 \mathrm{a}$ & $7.5 \pm 2.6 a$ & $33.66 \pm 8.30 \mathrm{a}$ & $87.40 \pm 26.92 \mathrm{a}$ & $41.14 \pm 13.91 \mathrm{a}$ \\
\hline \multirow[t]{6}{*}{$10-20$} & $\mathrm{HA}+\mathrm{N}$ & $1.6 \pm 0.6 \mathrm{a}$ & $26.0 \pm 16.6 \mathrm{a}$ & $6.8 \pm 2.5 \mathrm{a}$ & $34.39 \pm 16.66 a$ & $79.63 \pm 19.48 \mathrm{a}$ & $44.28 \pm 23.98 \mathrm{a}$ \\
\hline & $\mathrm{HA}+\mathrm{N}+\mathrm{L}$ & $1.6 \pm 1.1 \mathrm{a}$ & $30.3 \pm 21.0 \mathrm{a}$ & $7.6 \pm 4.0 \mathrm{a}$ & $39.51 \pm 26.05 a$ & $78.84 \pm 11.92 \mathrm{a}$ & $48.97 \pm 28.04 \mathrm{a}$ \\
\hline & $\mathrm{L}$ & $1.3 \pm 0.6 \mathrm{a}$ & $20.0 \pm 9.9 a$ & $7.0 \pm 2.9 \mathrm{a}$ & $28.28 \pm 12.92 \mathrm{a}$ & $104.49 \pm 34.08 \mathrm{a}$ & $27.34 \pm 11.65 a$ \\
\hline & $\mathrm{HA}+\mathrm{L}$ & $1.5 \pm 0.3 \mathrm{a}$ & $15.0 \pm 4.1 \mathrm{a}$ & $4.8 \pm 3.0 \mathrm{a}$ & $21.21 \pm 6.82 \mathrm{a}$ & $93.07 \pm 39.81 \mathrm{a}$ & $25.46 \pm 13.57 \mathrm{a}$ \\
\hline & $\mathrm{N}$ & $1.1 \pm 0.3 \mathrm{a}$ & $24.0 \pm 13.5 \mathrm{a}$ & $6.3 \pm 2.9 \mathrm{a}$ & $31.32 \pm 14.71 \mathrm{a}$ & $79.18 \pm 11.16 \mathrm{a}$ & $41.97 \pm 25.43 \mathrm{a}$ \\
\hline & $\mathrm{N}+\mathrm{L}$ & $1.2 \pm 0.3 \mathrm{a}$ & $19.8 \pm 6.9 \mathrm{a}$ & $4.5 \pm 3.0 \mathrm{a}$ & $25.45 \pm 9.35 \mathrm{a}$ & $82.35 \pm 20.20 \mathrm{a}$ & $32.30 \pm 14.03 \mathrm{a}$ \\
\hline
\end{tabular}

Distinct letters by column in each soil depth indicate significant differences (ANOVA with Duncan test, $\mathrm{p}<0.05$ ).

$\mathrm{HA}+\mathrm{N}$ (humic acid+nitrogen), HA+N+L (humic acid+nitrogen+leucaena), L (leucaena), HA+L (humic acid+leucaena), N (nitrogen), N+ L (nitrogen+leucaena).

Fonte: Autores

\subsection{Relations between different soil fertilization regimes, soil chemical attributes and maize grains yield}

Available $\mathrm{P}, \mathrm{Ca}^{2+}, \mathrm{Mg}^{2+}$ and $\mathrm{SBC}$ only showed positive correlations with maize grains yield in the $0-5 \mathrm{~cm}$ soil depth, especially at N. CEC, BS, SOC and the acidity parameters ( $\mathrm{pH}$ and potential acidity) did not show any correlation with maize grains yield in the soil profile $(0-20 \mathrm{~cm})$ (Figures $3 \mathrm{a}, 3 \mathrm{~b}$ and $3 \mathrm{c}$ ).

Potential acidity always showed negative correlation with all attributes, except with CEC in all soil depths. The pH was positively associated with both $\mathrm{SBC}$ and $\mathrm{BS}$, while $\mathrm{Mg}^{2+}$ was always positively related to SBC in the $0-20 \mathrm{~cm}$ soil depth. Nitrogen alone or mixed showed positive association with maize grains yield in $0-10 \mathrm{~cm}$ soil depth, while $\mathrm{HA}+\mathrm{L}$ and $\mathrm{L}$ did not show any association in soil profile $(0-20 \mathrm{~cm})$ (Figures $3 \mathrm{a}, 3 \mathrm{~b}$ and $3 \mathrm{c})$. 
Figure 3. Results of principal components analysis at 0-5 cm (a), 5-10 cm (b) and 10-20 cm soil depth (c) in different soil fertilization regimes.
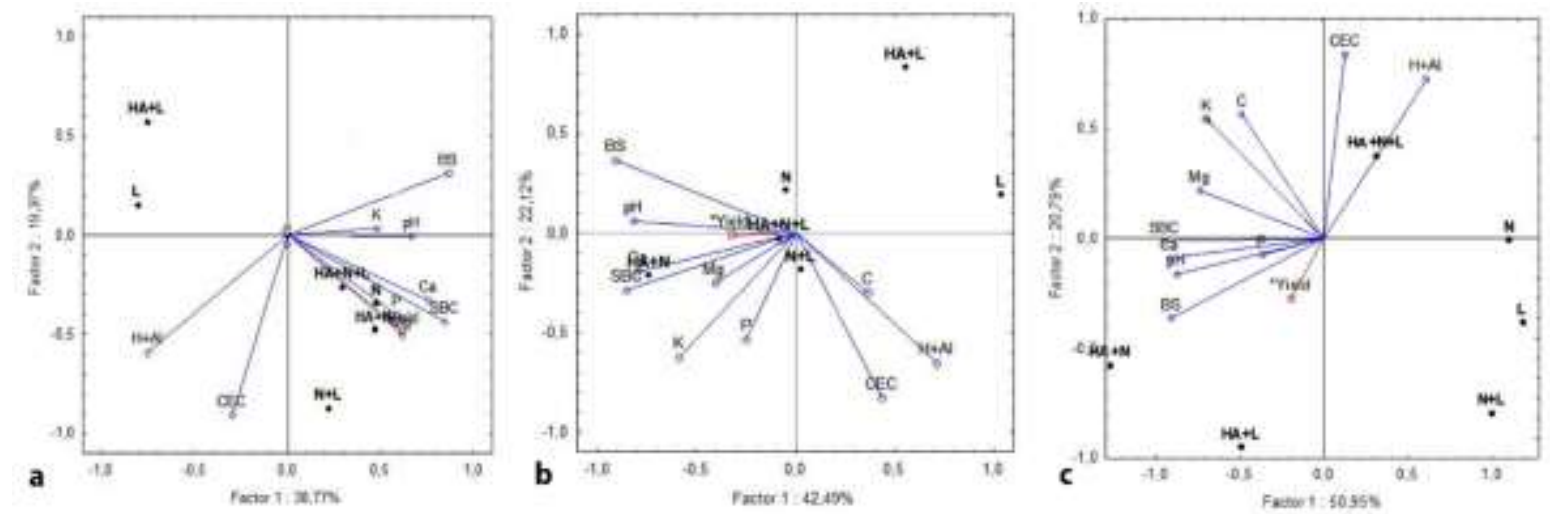

Fonte: Autores.

\section{Discussion}

\subsection{Maize grains yield}

Nitrogen fertilizer showed a significant increase in maize grains yield ( $\mathrm{p}<0.05$ ), as predicted by Li et al. (2019) and Yang et al. (2017), who point out that crops generally respond very well to the application of nitrogen fertilizer. Wang et al. (2008) reported that the main nutrient to increase maize yield is $\mathrm{N}$, which also interferes positively in the grain proteins concentration. For Qiang et al. (2019), beyond N availability, the maize genotype also is an essential factor for growth and grains yield. According to Martins et al. (2018), nitrogen fertilization influences soil fauna, which can increase maize grains yield, since it can enhance the soil structure and nutrients composition, due to importance that it occupies as soil engineers and decomposers of organisms remains.

The higher maize grains yield at $\mathrm{N}+\mathrm{L}(\mathrm{p}<0.05)$ is according Gai et al. (2016), for which this combined application enhances soil fertility, crops yield and sustainability, being better than application of chemical or organic fertilizer alone. According Afolayan and Oyetunji (2018), besides improving soil structure, organic materials increase the soil organic carbon content, then enhancing crop yield. In this sense, Zhong et al. (2018) emphasize the importance of green manure using legumes, which alter soil bacterial community structure, enhancing soil fertility. Inclusion of leucaena pruning provides additional nutrients and benefits of organic matter to soils, leading to increase in maize grains yield (Mugendi et al., 1999), as well as to increased removal and efficiency of inorganic $\mathrm{N}$ use in tropical cohesive soils in the same region (Aguiar et al., 2018).

\subsection{Effect of different soil fertilization regimes on soil chemical properties}

In general, while the potential acidity increased with increasing soil depth, the $\mathrm{pH}$ decreased. According to Shukla et al. (2013), this can be caused by the formation of acids due to the percolation of the water in the deeper layers of the soil. In fact, the lower the $\mathrm{pH}$, the higher the acidity. In this sense, it is important to clarify that while pH considers only hydrogen ions, the potential acidity considers hydrogen ions of various chemical combinations and adsorbed on the solid particles' surfaces (Allaway, 1957). The $\mathrm{pH}$ only showed difference between treatments in the upper soil layer ( $\mathrm{p}<0.05$ ), but no significant difference as a function of depth, as Davenport et al. (2003) also noted in their research. The humic acid may have led to increasing in acidification of the soil at HA+L treatment in upper layer (Dobbs et al., 2009), maximizing its effect by the organic matter from leucaena. 
With increasing soil depth, the concentrations of available P tended to decrease, as Franzluebbers and Hons (1996) detected. This decreasing was also recorded for Milić et al. (2019), who affirm that this occurs because the soil upper layer serves as a nutrient deposition site. According Ehrenfeld et al. (2005), cations redistribution through the soil is influenced by plants, and phosphorus is highly concentrated in upper soil, because it is a cation with high concentrations in vegetable tissues. Since agricultural systems do not function as a natural environment, both the dynamics and the quantity and nutrients availability, such as phosphorus, receive great human influence (Milić et al., 2019). In this context, Maharjan et al. (2018) showed that land alterations have a great influence on the phosphorus concentration in soil. However, there were no significant differences in available $\mathrm{P}$ concentrations between treatments in the present study $(\mathrm{p}>0.05)$.

We found that SOC concentrations showed a tendency to decrease with increasing soil depth, as well as in the study done by Li et al. (2019), who related this decreasing to the vertical distribution of the crop root system. They also suggested that the SOC distribution in the soil profile depends on both the soil type and source material. However, Yang et al. (2018) recorded that soil depth was positively related to the SOC. In this context, Lorenz and Lal (2005) affirm that soil organic matter (SOM) increases with depth due to its chemical recalcitrance and turnover time, and this favors the increase in SOC in deeper layers. For Arif et al. (2016), when organic materials are added in the soil, the SOC tend to increase. Nevertheless, we did not find these results where organic fertilizers were used.

$\mathrm{N}+\mathrm{L}$ treatment showed a significant increase in $\mathrm{K}^{+}$and $\mathrm{Ca}^{2+}$ concentrations, compared with $\mathrm{N}$ alone, at $0-5 \mathrm{~cm}$ soil depth ( $\mathrm{p}<0.05$ ). Leucena is a source not only of $\mathrm{N}$, but also of other nutrients such as potassium and calcium, although influences less the latter (Lupwayi and Haque, 1998). According to Ordóñez-Fernández et al. (2015), residues as leucaena, besides providing protection, also enrich the soil with nutrients, depending on both the residue amount and composition, and on its decomposition process. These researchers found that $\mathrm{K}^{+}$content was influenced by pruning residues, as in the present study. In this sense, they pointed out that potassium is easily released from the residues during decomposition when rainfall is favorable, probably due to the presence of this element in mobile cations released when the cell membrane ruptures.

The use of $\mathrm{HA}+\mathrm{N}+\mathrm{L}$ resulted in highest concentrations of SBC and BS at $0-5 \mathrm{~cm}$ soil depth $(\mathrm{p}<0.05)$. Legumes used as green manures increase soil organic matter and, consequently, SBC and BS, especially in tropical soils (Delarmelinda et al., 2010). Since humic acid is derived from soil organic matter (Mindari et al., 2014), when added to the legume and nitrogen fertilizer, may have potentiated its effects on SBC and BS.

$\mathrm{HA}+\mathrm{L}$ recorded highest concentration of CEC in the soil upper layer $(\mathrm{p}<0.05)$. According to Carvalho et al. (2014), organic matter accumulated in the topsoil can lead to the increase in the CEC, due to the increase in soil negative charges. Delarmelinda et al. (2010) explain that the largest percentage of total CEC in tropical soils originates from organic matter (70$90 \%)$.

\subsection{Relations between different soil fertilization regimes, soil chemical attributes and maize grains yield}

Available $\mathrm{P}$, exchangeable $\mathrm{Ca}^{2+}$ and $\mathrm{Mg}^{2+}$ were positively associated with maize grains yield in soil superficial layer, especially at nitrogen fertilization. Salvagiotti et al. (2017) point out that crop growth during grains number formation is positively impacted by nutrients availability, which can consequently to increase maize yield. Some macronutrients as calcium and magnesium collaborate to crop development and metabolism (Cakmak, 2001), through essential constituents' fabrication (Cronk and Fennessy, 2001) and strengthening of plant structure, contributing to agricultural yield. Phosphorus is a very important nutrient to increase maize yield (Adepetu, 1993) and its deficiency in soil decreases until the plant photosynthetic rate (Zhang et al., 2018). Furthermore, phosphorus is involved with enzymatic reactions, cell division, carbohydrate synthesis and degradation, crop maturation, fortification of the plant skeletal structure and grains quality (Onasanya et al., 2009). The 
present study showed that SBC also is related to maize grains yield, but Brunn et al. (2006) did not find this relation in their research using cereal. High SBC may indicate increased soil fertility, which may also lead to increased yield.

Nitrogen alone or mixed and maize grains yield were associated by PCA in $0-10 \mathrm{~cm}$ soil depth, confirming ANOVA results. One of the main techniques to enhance crop yield is to increase application of $\mathrm{N}$ fertilizers (Guo et al., 2010), and according to Moser et al. (2006), this nutrient is one of most limiting factors for maize grains yield.

Acidity-related parameters showed some associations. Potential acidity only was positively related to CEC, since it is used to estimate the concentration of this variable. The $\mathrm{pH}$ was positively associated to both SBC and BS in all layers, as Abreu Jr. et al. (2003) also recorded at Brazilian soils. Moreira and Fageria (2009), also researching Brazilian dystrophic soils, showed that $\mathrm{pH}$ and BS were positively correlated and presented low contents due to the high degree of intemperization that occurs in this type of soil.

\section{Conclusion}

The main results of this research indicate that combination between an organic and an inorganic source of nitrogen at $\mathrm{N}+\mathrm{L}$ treatment led to the increase in maize grains yield and, in this sense, the legume presence was essential to enhance fertility due to alteration of soil bacterial community. The presence of leucaena at $\mathrm{N}+\mathrm{L}$ led to increase in potassium and calcium concentrations, because leucaena enriches the soil with these nutrients. Legume and humic acid presence together probably increased organic matter content at $\mathrm{HA}+\mathrm{N}+\mathrm{L}$ and $\mathrm{HA}+\mathrm{L}$, increasing soil negative charges, leading to the highest SBC and BS concentrations and CEC concentration, respectively. Calcium, magnesium, and phosphorus were associated with maize grains yield in topsoil especially in nitrogen fertilization, since these nutrients cooper with crop metabolism, producing essential constituents and enhancing the plant structure. This study confirms the hypothesis that there is a linkage between different soil fertilization regimes, soil properties and the maize grains yield.

Despite the results obtained here, it is suggested that other studies consider a larger sample so that more robust conclusions can be reached.

\section{Acknowledgements}

We would like to thank Fundação de Amparo à Pesquisa e ao Desenvolvimento Científico e Tecnológico do Maranhão - FAPEMA.

\section{References}

Abreu Jr., C. H., Muraoka, T. \& Lavorante, A. F. (2003). Relationship between acidity and chemical properties of Brazilian soils. Scientia Agricola, 60(2), 337-343. 10.1590/S0103-90162003000200019.

Adepetu, J. A. (1983). Phosphorus fertilization of tropical crops. In Nutrients Supply to Tropical Crops, 21-288 (Eds Mutscher and Franke). Institute of Trop. Agric, Leipzig Publ.: https://scholar.google.com/scholar_lookup?hl=en\&publicationyear=1983\&pages=211238\&author=J.+A.+Adepetu\&title=+Nutrient+supply+to+ tropical+crops + .

Afolayan, E. T. \& Oyetunji, J. O. (2018). Influence of Arbuscular Mycorrhizal Fungi, Green Manure of Leucaena leucocephala and Gliricidia sepium on the Yield of White Yam (Dioscorea rotundata) and Soil Bioremediation in the Abandoned Quarry. Agricultural Extension Journal, 2(1), 51-54. http://www.aextj.com/index.php/aextj/article/view/60/40.

Aguiar, A. C. F., Souza, E. A., Cardoso-Silva, A. J. \& Moura, E. G. (2019). How leguminous biomass can increase yield and quality of maize grain in tropical agrosystems. Legume Research, 1-7. 10.18805/LR-380.

Allaway, W. H. (1957). pH, soil acidity and plant growth. In Soil The Yearbook of Agriculture, 67-71 (Ed. A. Stefferud). Washington: USDA. https://naldc.nal.usda.gov/download/IND43894850/PDF.

Anh, P. T. Q., Gomi, T., MacDonald, L. H., Mizugaki, S., Khoa, P. V. \& Furuichi, T. (2014). Linkages among land use, macronutrient levels, and soil erosion in northern Vietnam: A plot-scale study. Geoderma, 232-234(6), 352-362. 10.1016/j.geoderma.2014.05.011. 
Arif, M., Ali, K., Jan, M. T., Shah, Z., Jones, D. L. \& Quilliam, R. S. (2016). Integration of biochar with animal manure and nitrogen for improving maize yields and soil properties in calcareous semi-arid agroecosystems. Field Crop Research, 195, 28-35. 10.1016/j.fcr.2016.05.011.

Bruun, T. B., Mertz, O. \& Elberling, B. (2006). Linking yields of upland rice in shifting cultivation to fallow length and soil properties. Agriculture, Ecosystems and Environment, 113, 139-149. 10.1016/j.agee.2005.09.012.

Cakmak, I. (2002). Plant and Soil, 247(1), 3-24. 10.1023/A:1021194511492.

Carvalho, A. M., Marchão, R. L., Souza, K. W. \& Bustamante, M. M. C. (2014). Soil fertility status, carbon and nitrogen stocks under cover crops and tillage regimes. Revista Ciência Agronômica, 45(5), 914-921. http://ccarevista.ufc.br/seer/index.php/ccarevista/article/view/3505/1053.

Cronk, J. K. \& Fennessy, M. S. (2001). Wetland Plants: Biology and Ecology. Boca Raton: Lewis. 10.1201/9781420032925.

Davenport, J. R., DeMoranville, C. J., Hart, J., Kumidini, S., Patten, K., Poole, A. \& Roper, T. R. (2003). Spatial and temporal variability of cranberry soil pH. Acta Horticulturae, 626(44), 315-327. 10.17660/ActaHortic.2003.626.44.

Delarmelinda, E. A., Sampaio, F. A. R., Dias, J. R. M., Tavella, L. B. \& Silva, J. S. (2010). Green manure and changes on chemical characteristics of a soil in the Ji-Paraná-RO region. Acta Amazonica, 40(3), 625-628. 10.1590/S0044-59672010000300024.

Dobbss, L. B., Rumjaneck, V. M., Baldotto, M. A., Velloso, A. C. X. \& Canellas, L. P. (2009). Caracterização química e espectroscópica de ácidos húmicos e fúlvicos isolados da camada superficial de latossolos brasileiros. Revista Brasileira de Ciência do Solo, 33(1), 51-63. 10.1590/S0100-06832009000100006.

Ehrenfeld, J. G., Ravit B. \& Elgersma, K. (2005). Feedback in the plant-soil system. Annual Review of Environment and Resources, 30(1), 75-115. 10.1146/annurev.energy.30.050504.144212.

Franzluebbers, A. J. \& Hons, F. M. (1996). Soil-profile distribution of primary and secondary plant available nutrients under conventional and no tillage. Soil Tillage and Research, 39, 229-239. doi.org/10.1016/S0167-1987(96)01056-2.

Gai, X., Liu, H., Zhai, L., Tan, G., Liu, J., Ren, T. \& Wang, H. (2016). Vegetable yields and soil biochemical properties as influenced by fertilization in Southern China. Applied Soil Ecology, 107, 170-181. 10.1016/j.apsoil.2016.06.001.

Guo, J. H., Liu, X. J., Zhang, Y., Shen, J. L., Han, W. X., Zhang, W. F., Christie, P., Goulding, K. W. T., Vitousek, P. M. \& Zhang, F. S. (2010). Significant acidification in major chinese croplands. Science, 327(5968), 1008-1010. 10.1126/science.1182570.

Li, Y., Li, Z., Cui, S., Chang, S. X., Jia, C. \& Zhang, Q. (2019). A global synthesis of the effect of water and nitrogen input on maize (Zea mays) yield, water productivity and nitrogen use efficiency. Agricultural and Forest Meteorology, 268(11), 136-145. 10.1016/j.agrformet.2019.01.018.

Lorenz, K. \& Lal, R. (2005). The Depth Distribution of Soil Organic Carbon in Relation to Land Use and Management and the Potential of Carbon Sequestration in Subsoil Horizons. Advances in Agronomy, 88, 35-66. 10.1016/S0065-2113(05)88002-2.

Lupwayi, N. Z. \& Haque, I. (1998). Mineralization of N, P, K, Ca and Mg from Sesbania and Leucaena leaves varying in chemical composition. Soil Biology \& Biochemistry, 30(3), 337-343. 10.1016/S0038-0717(97)00132-6.

Maathuis, F. J. M. (2009). Physiological functions of mineral macronutrients. Current Opinion in Plant Biology, 12(3), 250-258. 10.1016/j.pbi.2009.04.003.

Maharjan, M., Maranguit, D. \& Kuzyakov, Y. (2018). Phosphorus fractions in subtropical soils depending on land use. European Journal of Soil Biology, 87, 17-24. 10.1016/j.ejsobi.2018.04.002.

Martins, A. L. P., Siqueira, G. M., Moura, E. G., Silva, R. A., Silva, A. J. C. \& Aguiar, A. C. F. (2018). Associations between different soil management practices, soil fauna and maize yield. Journal of Agricultural Science, 10(9), 333-343. 10.5539/jas.v10n9p333.

Milić, S., Ninkov, J., Zeremski, T., Latković, D., Šeremešić, S., Radovanović, V. \& Žarković, B. (2019). Soil fertility and phosphorus fractions in a calcareous chernozem after a long-term field experiment. Geoderma, 339, 9-19. 10.1016/j.geoderma.2018.12.017.

Mindari, W., Aini, N., Kusuma, Z. \& Syekhfani, S. (2014). Effects of humic acid-based buffer + cation on chemical characteristics of saline soils and maize growth. Journal of Degraded Andmining Landsmanagement, 2(1), 259-268. 10.15243/jdmlm.2014.021.259.

Morar, F. \& Peterlicean, A. (2014). Studies and research regarding the main macronutrients content of some Mureș county soils. Procedia Technology, 12, 609-614. 10.1016/j.protcy.2013.12.537.

Moreira, A. \& Fageria, N. K. (2009). Soil Chemical Attributes of Amazonas State, Brazil. Communications in Soil Science and Plant Analysis, 40(17-18), 114. $10.1080 / 00103620903175371$.

Morgan, J. B. \& Connolly, E. L. (2013). Plant-Soil Interactions: Nutrient Uptake. Nature Education Knowledge, 4(8), 2. https://www.nature.com/scitable/knowledge/library/plant-soil-interactions-nutrient-uptake-105289112.

Moura, E. G. de, Silva, A. J. de F., Furtado, M. B. \& Aguiar, A. das C. F. (2008). Avaliação de um sistema de cultivo em aléias em um argissolo francoarenoso da região amazônica. Manejo e conservação do solo e da água, Revista Brasileira de Ciência do Solo, 32(4), 1735-1742. https://doi.org/10.1590/S0100-06832008000400038.

Moura, E. G., Moura, N. G., Marques, E. S., Pinheiro, K. M., Sobrinho, J. R. S. C. \& Aguiar, A. C. F. (2009). Evaluating chemical and physical quality indicators for a structurally fragile tropical soil. Soil Use and Management, 25(4), 368-375. 10.1111/j.1475-2743.2009.00238.x.

Mugendi, D. N., Nair, P. K. R., Mugwe, J. N., O’Neill, M. K. \& Woomer, P. L. (1999). Alley cropping of maize with calliandra and leucaena in the subhumid highlands of Kenya. Part 1. Soil-fertility changes and maize yield. Agroforestry Systems, 46, 39-50. https://link.springer.com/article/10.1023/A:1006288301044. 
Research, Society and Development, v. 10, n. 16, e366101623558, 2021

(CC BY 4.0) | ISSN 2525-3409 | DOI: http://dx.doi.org/10.33448/rsd-v10i16.23558

Onasanya, R. O., Aiyelari, O. P., Onasanya, A., Oikeh, S., Nwilene, F. E., Oyelakin, O. O. (2009). Growth and Yield Response of Maize (Zea mays L.) to Different Rates of Nitrogen and Phosphorus Fertilizers in Southern Nigeria. World Journal of Agricultural Sciences, 5(4), 400-407. https://pdfs.semanticscholar.org/ec32/5c9cdc804a04026cedca1a4efdbf603eeecb.pdf.

Ordóñez-Fernández, R., Torres, M. A. R., Román-Vázquez, J., González-Fernández, P. \& Carbonell-Bojollo, R. (2015). Macronutrients released during the decomposition of pruning residues used as plant cover and their effect on soil fertility. Journal of Agricultural Science, 153(4), 615-630. $10.1017 /$ S0021859614000458.

Qiang, S., Zhang, Y., Fan, J., Zhang, F., Xiang, Y., Yan, S. \& Wu, Y. (2019). Maize yield, rainwater and nitrogen use efficiency as affected by maize genotypes and nitrogen rates on the Loess Plateau of China. Agricultural Water Management, 213(C), 996-1003. 10.1016/j.agwat.2018.12.021.

Raij, B. V., Andrade, J. C., Cantarella, H. \& Quaggio, J. A. (2001). Análise química para avaliação da fertilidade de solo tropicais. Campinas: Instituto Agronômico.

Salvagiotti, F., Prystupa, P., Ferraris, G., Couretot, L., Magnano, L., Dignani, D. \& BGutiérrez-Boemoem, F. H. G. (2017). N:P:S stoichiometry in grains and physiological attributes associated with grain yield in maize as affected by phosphorus and sulfur nutrition. Field Crops Research, 203, 128-138, 10.1016/j.fcr.2016.12.019.

Shukla, A., Vyas, D. \& Jha, A. (2013). Soil depth: an overriding factor for distribution of arbuscular mycorrhizal fungi. Journal of Soil Science and Plant Nutrition, 13(1), 23-33. 10.4067/S0718-95162013005000003.

Soil Survey Staff. (2010). Keys to Soil Taxonomy. 11ed. Washington: USDA-Natural Resources Conservation Service.

Statsoft Inc. (2004). Statistica (version 7). Tusla, USA.

Wang, Z. H., Li, S. X. \& Malhi, S. (2008). Effects of fertilization and other agronomic measures on nutritional quality of crops. Journal of the Science of Food and Agriculture, 88, 7-23. 10.1002/jsfa.3084.

Yang, S., Cammeraat, E., Jansen, B., Haan, M. den, Loon, E. van \& Recharte, J. (2018). Peruvian alpine grassland of the Andes. Catena, 171, 11-21. 10.1016/j.catena.2018.06.038.

Yang, X., Lu, Y., Ding, Y., Yin, X., Raza, S. \& Tong, Y. (2017). Optimising nitrogen fertilisation: A key to improving nitrogen-use efficiency and minimising nitrate leaching losses in an intensive wheat/maize rotation (2008-2014). Field Crops Research, 206(C), 1-10. 10.1016/j.fcr.2017.02.016.

Zhang, W., Chen, X. X., Liu, Y. M., Liu, D. Y., Du, Y. F., Chen, X. P. \& Zou, C. Q. 2018. The role of phosphorus supply in maximizing the leaf area, photosynthetic rate, coordinated to grain yield of summer maize. Field Crops Research, 219, 113-119. 10.1016/j.fcr.2018.01.031.

Zhong, Z., Huang, X., Feng, D., Xing, S. \& Weng, B. (2018). Long-term effects of legume mulching on soil chemical properties and bacterial community composition and structure. Agriculture, Ecosystems and Environment, 268, 24-33. 10.1016/j.agee.2018.09.001. 